\title{
Supergene alteration of a refractory epithermal gold mineralization: The Perama Hill deposit, NE Greece
}

\author{
Triantafyllidis S. ${ }^{1}$, Skarpelis $\mathbf{N} .{ }^{2}$ \\ ${ }^{1}$ School of Mining and Metallurgical Engineering, Section of Geologic Sciences, \\ National Technical University of Athens, 9 Iroon Polytechneiou str., 157 80, Zografou, Athens, Greece \\ ${ }^{2}$ Faculty of Geology and Geoenvironment, Panepistimiopoli 157 84, Zografou, Athens, Greece \\ Tel.: 210-7724468, email: striantafyllidis@metal.ntua.gr
}

\begin{abstract}
Supergene alteration phenomena have affected the upper part of the Perama Hill epithermal mineralization hosted in the felsic sandstone (oxide sector). The very low acid buffering capacity of the porous sandstone combined with the disseminated character of pyrite and sulfosalts, resulted in extensive weathering. Goethite and hematite predominate in the upper part of the mineralized sandstone revealing pervasive oxidation and leaching of heavy metals. A transitional zone to the refractory sulfide mineralization is detected close to the underlying andesitic breccia. Free Au grains are identified in the upper, oxide sector of the deposit, with the highest Au grades being observed at the upper and lower part of the sandstone, the latter located close to the transition zone with the underlying andesitic breccia. Acid rock drainage identified in both surface and ground water samples in the vicinity of the Perama Hill epithermal deposit indicates active oxidation of the sulfide sector of the deposit.
\end{abstract}

Key words: Intermediate sulfidation, disseminated ore, oxidation, native Au

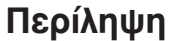

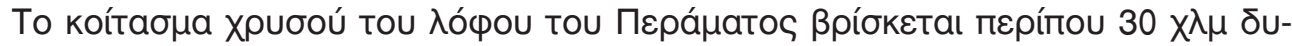

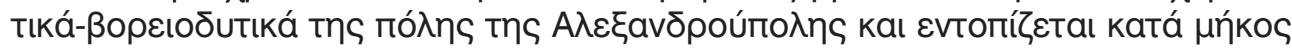

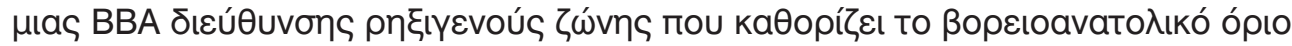

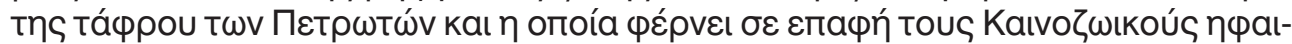

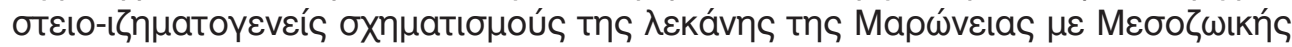

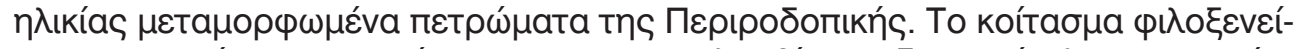

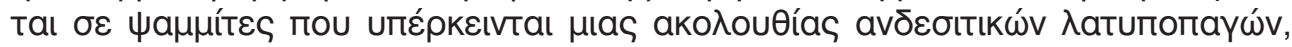

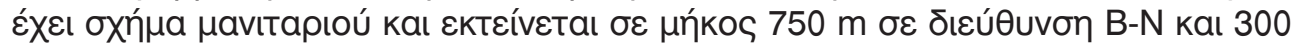

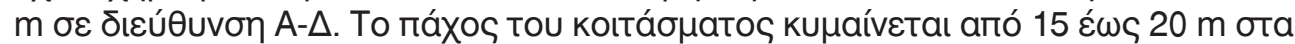

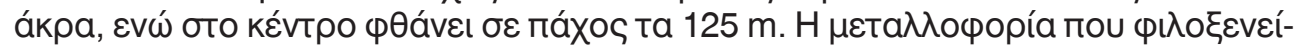

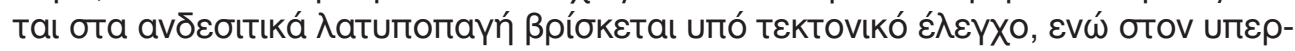

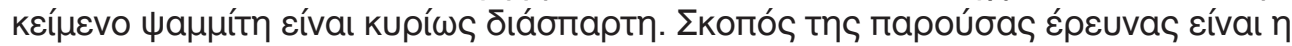

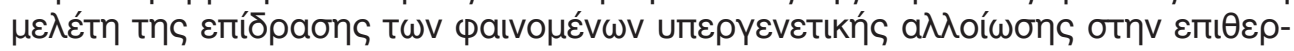

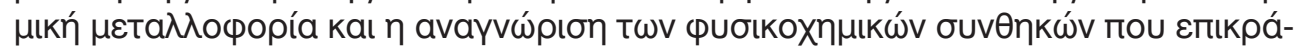

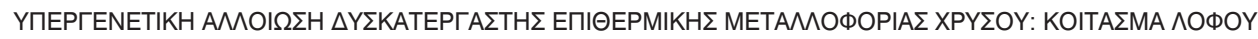
ПEPAMATO $\Sigma$, BA EM $M A$ A 


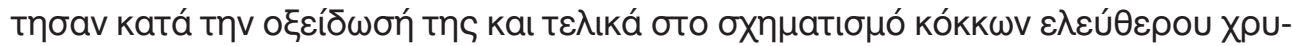

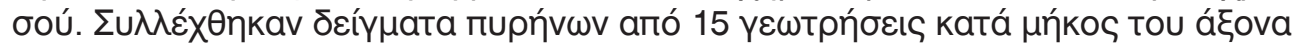

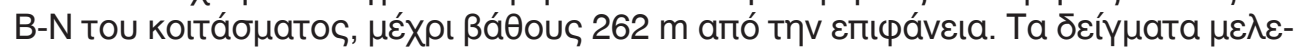

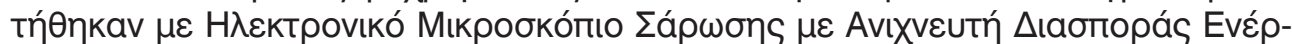

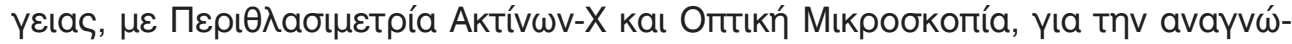

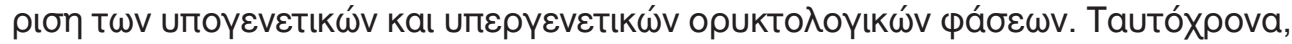

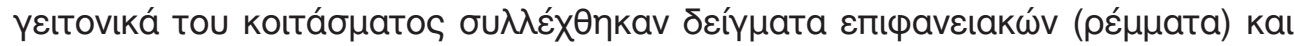

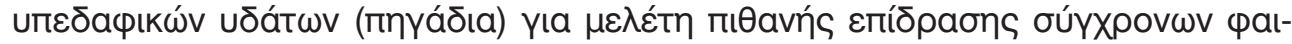

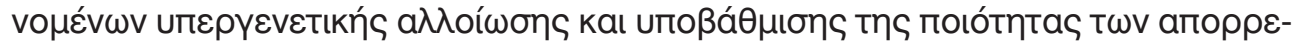

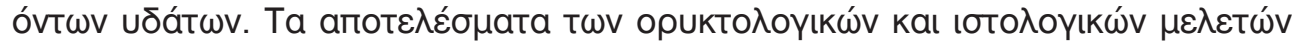

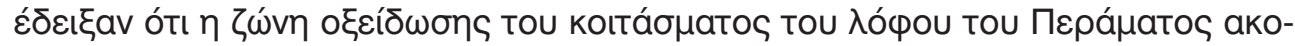

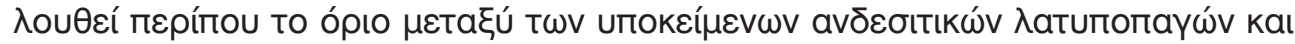

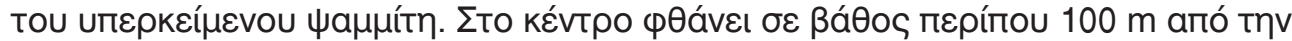

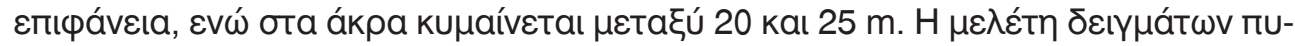

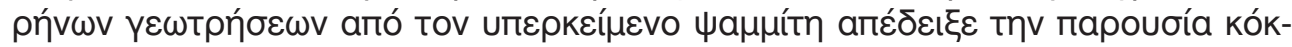

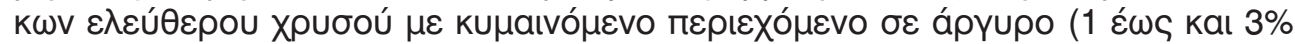

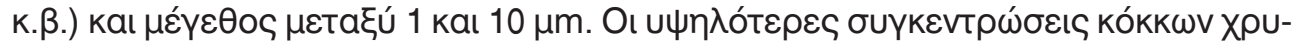

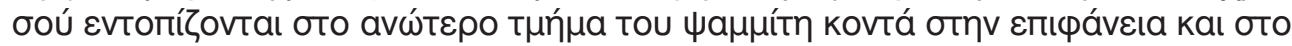

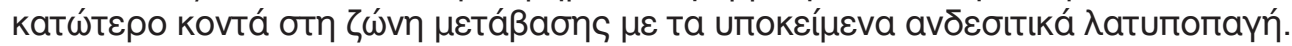

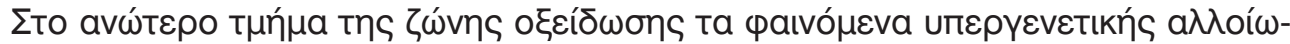

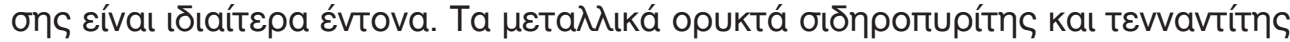

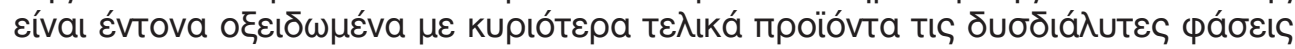

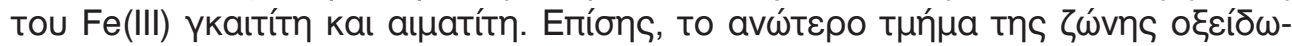

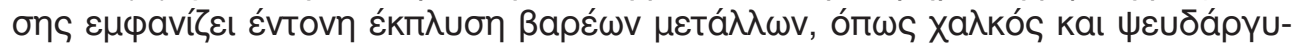

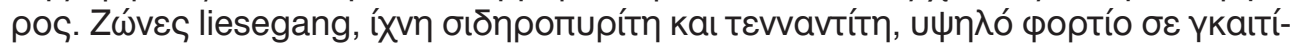

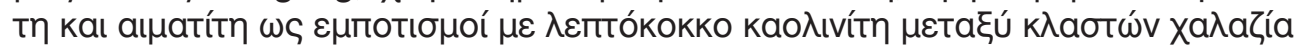

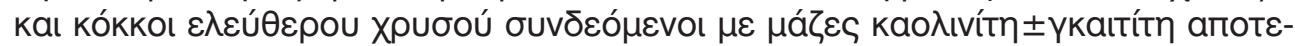

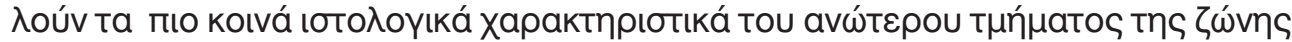

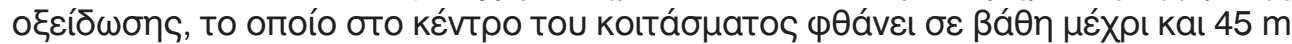

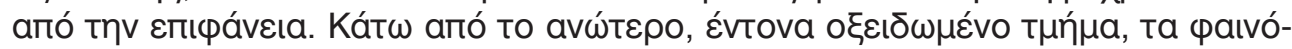

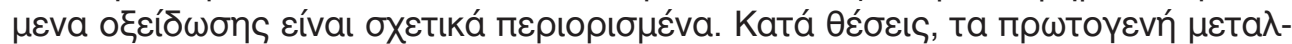

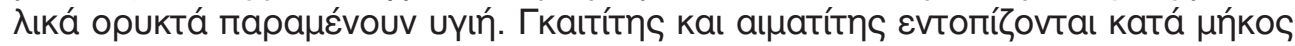

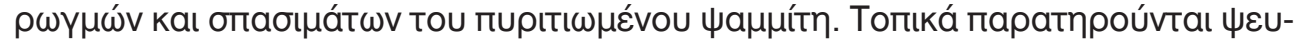

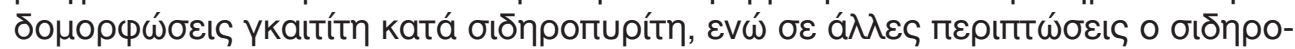

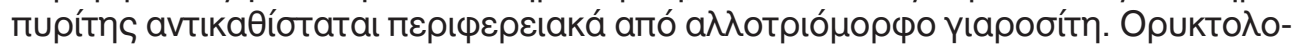

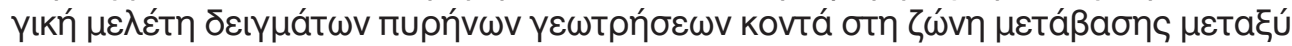

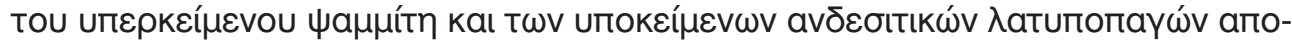
кá $\lambda \cup \psi \varepsilon$ tᄁ

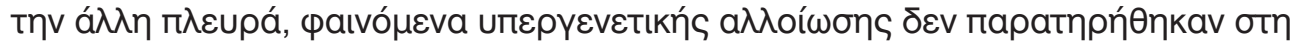

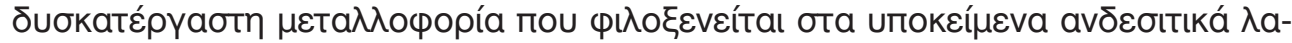

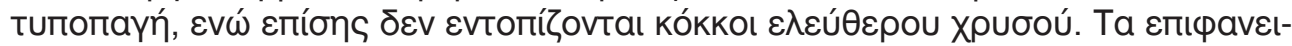

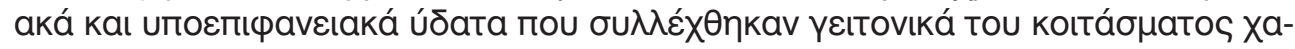

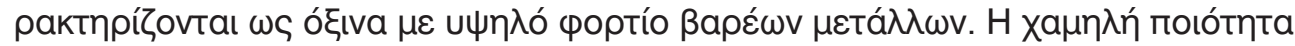

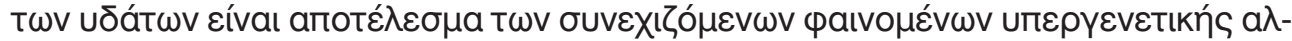

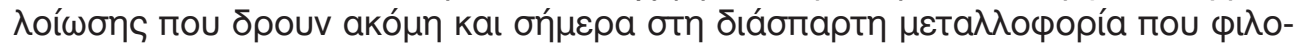

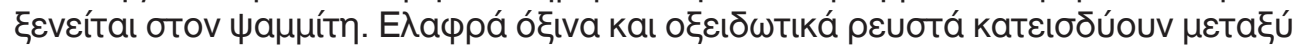




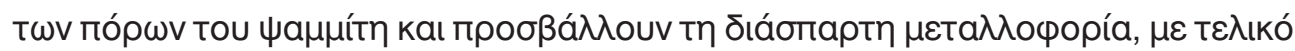

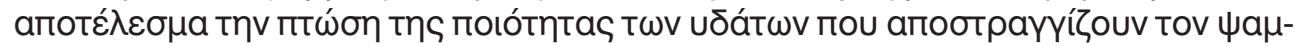

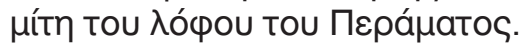

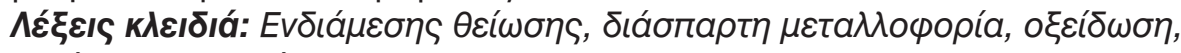

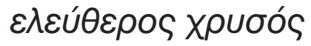

\section{Introduction}

A significant number of epithermal systems occur in several parts of the Tertiary volcanosedimentary basin of Thrace, NE Greece. Exploration for gold is still carried out to this day, recognising the Tertiary Thrace basin as a Au-rich terrain (Skarpelis, et al., 1987; Michael et al., 1988; Michael et al., 1989; Michael et al., 1995; Bridges et al., 1997; Skarpelis, et al., 1999; Voudouris et al., 2003) due to favourable structures and magmatism. Several epithermal Au prospects were investigated during the last 15 years in the area with those of Perama and Sapes being the most important, verifying the Au potential of Thrace (Border et al., 1999; McAlister et al., 1999; Shaw and Constantinides, 2001; Lescuyer et al., 2003).

The aim of the present paper is to determine the effect of supergene alteration of the epithermal mineralization at Perama hill and to identify the physicochemical conditions that prevailed during supergene alteration which led to free Au formation.

\section{Geological setting - ore deposit geology}

The Perama Hill gold deposit is located $30 \mathrm{~km}$ west-northwest of the city of Alexandroupolis, Thrace, NE Greece (Fig. 1A). The topography of the region consists of low altitude hills, with height ranging between 250 and $300 \mathrm{~m}$ above sea level. Vegetation is sparse comprising mainly thorn and scrub bushes and oak trees, and the climate is characterized as Mediterranean with mean annual rainfall of 560 $\mathrm{mm}$ (Juras et al., 2010).

The Perama Hill epithermal system is controlled by a NNE trending fault zone that defines the northeastern border of the Petrota graben and brings in contact the Cenozoic volcano-sedimentary formation of the Maronia basin with strongly deformed and drag folded Mesozoic marbles, greenschists and calc-schists of the Circum-Rhodope Belt (Lescuyer et al., 2003) (Fig. 1B). Transtensional opening of the graben during Late Eocene-Oligocene facilitated intrusion of calc-alkaline to high-K calc-alkaline magma bodies (Eleftheriadis, 1990; Christofides et al, 1998) with formation of extrusive and shallow level intrusive volcanic suites. Pecskay et al. (2003) distinguished two main periods of volcanic activity in the region, an Oligocene $(33.5-25.4 \mathrm{Ma})$ and a Lower Miocene (22.0 - $19.6 \mathrm{Ma})$, based on K/ Ar ages obtained from whole rock (lavas and tuffs) and biotite separates. During Oligocene, sinistral strike-slip reactivation of basement faults and graben margins is considered synchronous with the hydrothermal activity that led to the formation of the mineralization (Lescuyer et al., 2003).

The deposit is hosted in felsic volcanic sandstone overlying a sequence of andesitic volcanic breccia. A volcanoclastic conglomerate unit with ranging thickness marks the transition be- 
tween the two formations.

The sandstone is considered coeval with felsic eruptions at the western part of the graben and the presence of worm tubes and wood fragments indicate palustrine environment (Lescuyer et al., 2003).
The deposit is mushroom shaped and extends $750 \mathrm{~m}$ in a north-south direction and up to $300 \mathrm{~m}$ in an east-west direction with thickness varying from $15 \mathrm{~m}$ to $20 \mathrm{~m}$ at the borders and up to $125 \mathrm{~m}$ at the centre (Juras et al., 2010).

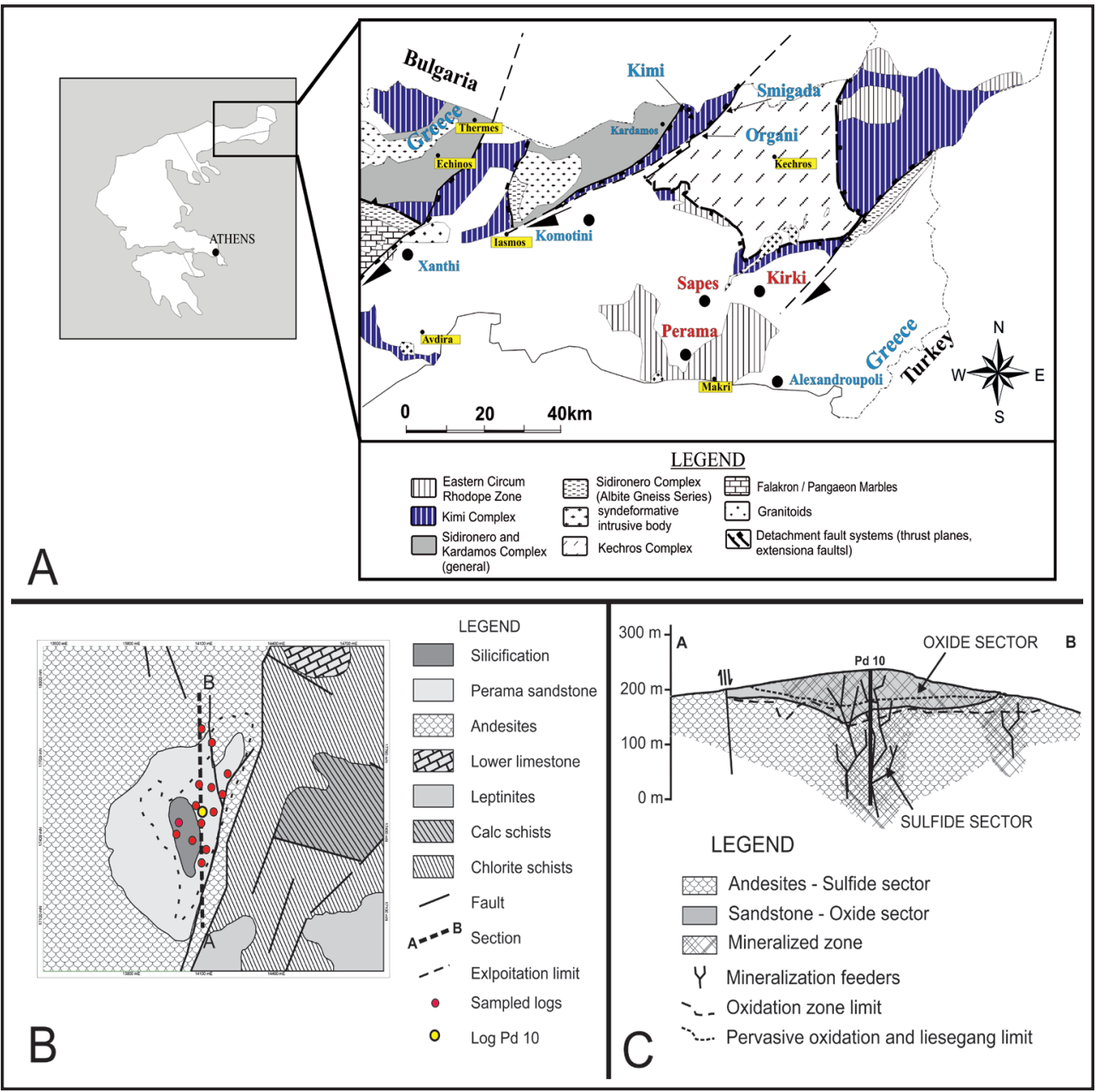

Fig. 1. A. Simplified geological map of Eastern Macedonia - Thrace, NE Greece (after Krohe and Mposkos, 2002). B. Geological map of the Perama Hill deposit with locations of sampled logs (courtesy of Thracean Goldmining S.A. with modifications). C. Cross section (N-S direction) of the Perama Hill deposit indicating the limit of the oxidation zone (after Triantafyllidis, 2006 with modifications).

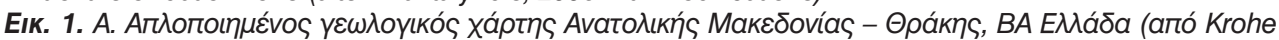

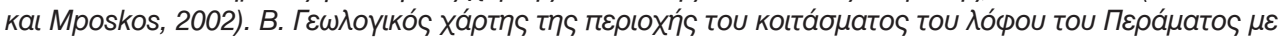

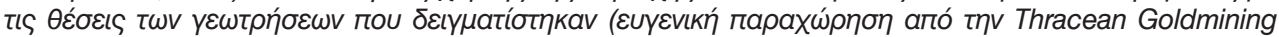

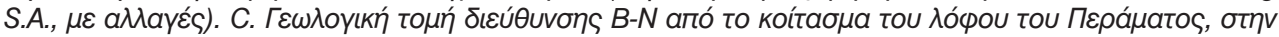

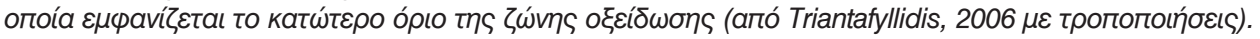


Hypogene mineralization is under tectonic control and occurs in distinct subvertical feeder zones, whereas in the overlying sandstone is mostly disseminated. The deposit is characterized as intermediate sulfidation (Skarpelis et al., 2006) or as high sulfidation overprinted by a later intermediate sulfidation stage (Voudouris et al., 2007).

Stable and radiogenic isotope data studies revealed the high to intermediate sulfidation character of the mineralization (Marschik et al., 2011). The deposit has been deeply oxidized and fine grained free gold mineralization is hosted in the sandstone (Skarpelis et al., 2006). Hence, two major sectors may be recognized in the Perama deposit: the upper, oxide sector with free gold which is the target for mineral exploitation by application of cyanide extraction technique, and the lower, sulfide sector. The calculated reserves (proven and probable) are 9.4 Mt with average grade $3.20 \mathrm{gr} / \mathrm{tn}$ $\mathrm{Au}$ and $3.75 \mathrm{gr} / \mathrm{tn} \mathrm{Ag}$. In the oxidized ore Au grades range between 5 and $10 \mathrm{~g} / \mathrm{tn}$ whereas in the underlying sulfide sector Au grades are below 1 $\mathrm{g} / \mathrm{tn}$ (Juras et al., 2010).

\section{Sampling - Analytical methods}

Drill core samples from 15 bore holes (Fig. 1B) along a N-S axis to depths down to $262 \mathrm{~m}$ were collected and used for the mineralogical investigation of both hypogene refractory mineralization and supergene mineral phases. Sampling was focused on those parts of drill cores where high in $\mathrm{Au}$ and base metals ore was detected, based on geochemical profiles and the grades provided by the company. A total number of 35 thin and polished sections were prepared, and a part from each sample was pulverized and homogenized for X-Ray diffraction. Mineral identification was carried out by combined optical microscopy, X-ray diffractometry and Scanning Electron Microscopy (SEM). X-ray diffractometry was carried out by using a SIEMENS D5005 X-ray diffractometer with $\mathrm{Cu}(\mathrm{ka})$ radiation at $40 \mathrm{kV} / 20 \mathrm{~mA}$ operating conditions. Scanning electron microscopy was performed using a Jeol JSM 5600 scanning electron microscope combined with energy dispersive X-ray spectrometry (OXFORD ISIS Link electron microprobe) and equipped with a Jeol Analytical back-scattered electron detector at the Laboratory of Economic Geology and Geochemistry, University of Athens. Operating conditions for the SEM were $20 \mathrm{kV}$ accelerating voltage and $0.5 \mathrm{nA}$ beam current. Counting time for each analysis was $50 \mathrm{sec}$, with $15 \mathrm{sec}$ dead time. Several geochemical profiles of selected heavy metals of the studied boreholes were provided by courtesy of Thracean Gold Mining S.A. and used for the mineralogical and textural investigation (Fig. 2).

Stream and groundwater samples from the vicinity of the deposit were collected in order to investigate whether supergene alteration phenomena are active, affecting surface drainage and underground waters. Sampling was carried out in June and October 2003 applying standard sampling techniques. Water samples were commercially analyzed for cations contents. Concentrations of $\mathrm{Fe}, \mathrm{Mn}, \mathrm{Cu}, \mathrm{Pb}, \mathrm{Zn}, \mathrm{Cd}$, $\mathrm{Ni}, \mathrm{Co}, \mathrm{As}, \mathrm{Hg}$, and $\mathrm{Sb}$ were determined by an inductively coupled 
plasma atomic emission spectrometer (ICP-AES). For Hg, the Hydride/ Cold vapor technique was applied in order to further lower the detection limit below $0.01 \mathrm{mg} / \mathrm{L}$. Temperature, $\mathrm{pH}$ and Eh were measured on site while sulphate concentrations were measured at the Laboratory of Economic Geology and Geochemistry, University of Athens, by spectrophotometry (Hach DR 2000).

\section{RESULTS}

\subsection{Hypogene mineralogy - Sulfide sector}

Pyrite is the predominant sulfide mineral in the Perama Hill deposit with its concentrations increasing along with depth (Tabl. 1, Fig. $2)$. Pyrite is mostly disseminated and rarely forms patches and aggregates. Marcasite usually occurs in crystal sizes ranging between 5 and $10 \mu \mathrm{m}$. Marcasite aggregates are observed along with pyrite. Tennantite and enargite participate in moderate proportions (Tables 1 and 2). Minor anglesite, sphalerite (mainly as inclusions in pyrite), $\mathrm{Pb}$-sulfosalts and tellurides are identified as well. In the sulfide sector, Au-bearing phases include $\mathrm{Au}$ and $\mathrm{Ag}$-Au tellurides in as- sociation with hessite and $\mathrm{Ag}-\mathrm{Bi}$ tellurides. No primary silicates besides quartz are observed, indicating hydrothermal alteration and replacement by silica and to a lesser degree by kaolinite. Svanbergite-woodhouseite series phases are found in samples from both the oxide and the sulfide sector of the deposit (Tabl. 1). These phases are fine-grained forming aggregates and patches with kaolinite and euhedral unaltered pyrite and may indicate hypogene origin related to development of advance argillic alteration (Dill, 2001). Svanbergite-woodhouseite phases are members of the alunite - jarosite supergroup - APS with a general formula $A_{3}\left(X_{4}\right)_{2}(O H)_{6}$. The anion $\mathrm{XO} 4-\mathrm{X}$ is occupied either by $\mathrm{S}$ or $\mathrm{P}$ (Struntz and Tennyson, 1982; Scott, 1987; Jambor, 1999) with alunite being the most common phase. Late stage acidic fluids with increased $P$ content may change alunite composition through coupled substitutions of $\left[\mathrm{K}^{+}+\mathrm{SO}_{4}^{-2}\right]$ by $\left[(\mathrm{Ca}, \mathrm{Sr})^{-2}+\mathrm{PO}_{4}^{-3}\right]$ towards svanbergite-woodhouseite solid solutions (Dill, 2001). No supergene alteration is observed and primary sulfides and sulfosalts still remain (Fig. 3A).

\begin{tabular}{|c|c|c|c|c|c|c|c|}
\hline \multicolumn{2}{|c|}{$\begin{array}{l}\text { Sulfides, sulfosalts, } \\
\text { native metals }\end{array}$} & \multicolumn{2}{|l|}{ Gangue } & \multicolumn{2}{|c|}{$\begin{array}{l}\text { Supergene } \\
\text { phases }\end{array}$} & \multicolumn{2}{|c|}{$\begin{array}{l}\text { Detrital phases in the } \\
\text { sandstone }\end{array}$} \\
\hline Pyrite & +++++ & Quartz & +++++ & Goethite & +++ & Rutile-anatase & ++ \\
\hline Tennantite & ++ & K-feldspar & + & Hematite & +++ & Zircon & + \\
\hline Enargite & ++ & Kaolinite & +++ & Jarosite & + & Monazite & + \\
\hline Galena & + & Illite & + & Anglesite & + & IImenite & ++ \\
\hline Sphalerite & + & Svanbergite-woodhouseite & + & & & Churchite & + \\
\hline $\mathrm{Pb}$-sulfosalts & + & Barite & ++ & & & & \\
\hline Marcasite & + & & & & & & \\
\hline Hessite & + & & & & & & \\
\hline Tetradymite & + & & & & & & \\
\hline Ag-Bi tellurides & + & & & & & & \\
\hline $\mathrm{Au}( \pm \mathrm{Ag})$ grains & + & & & & & & \\
\hline
\end{tabular}




\begin{tabular}{|c|c|c|c|c|c|}
\hline \multirow[b]{2}{*}{ Mn } & \multicolumn{2}{|c|}{ Tennantite } & \multicolumn{3}{|c|}{ Enargite } \\
\hline & 0.91 & 0.28 & b.d.l. & b.d.I. & b.d.l. \\
\hline $\mathrm{Fe}$ & 4.19 & 7.02 & 0.27 & 0.27 & 2.97 \\
\hline $\mathrm{Cu}$ & 39.52 & 36.19 & 46.11 & 45.93 & 43.81 \\
\hline $\mathrm{Zn}$ & 5.24 & 6.19 & b.d.l. & b.d.l. & b.d.l. \\
\hline As & 18.49 & 15.14 & 20.57 & 20.6 & 21.17 \\
\hline $\mathrm{Sb}$ & 3.05 & 7.13 & b.d.l. & b.d.l. & b.d.l. \\
\hline $\mathbf{S}$ & 27.15 & 27.99 & 31.19 & 31.07 & 32.18 \\
\hline TOTAL & 98.55 & 99.94 & 98.14 & 97.87 & 100.13 \\
\hline$M n$ & 0.25 & 0.08 & - & - & - \\
\hline $\mathrm{Fe}$ & 1.14 & 1.89 & 0.02 & 0.02 & 0.21 \\
\hline $\mathrm{Cu}$ & 9.43 & 8.56 & 2.94 & 2.93 & 2.72 \\
\hline $\mathrm{Zn}$ & 1.22 & 1.42 & - & - & - \\
\hline As & 3.74 & 3.04 & 1.11 & 1.12 & 1.11 \\
\hline Sb & 0.38 & 0.88 & - & - & - \\
\hline S & 12.84 & 13.12 & 3.93 & 3.93 & 3.96 \\
\hline TOTAL & 29 & 28.99 & 8 & 8 & 8 \\
\hline
\end{tabular}

\begin{tabular}{|c|c|c|c|c|c|}
\hline \multicolumn{6}{|c|}{$\begin{array}{l}\text { Tabl. 3. Representative chemical analyses of jarosite (out of } 65 \text { ) from the Perama Hill deposit (results in } \\
\text { wt } \% \text { ). }\end{array}$} \\
\hline $\mathrm{K}_{2} \mathrm{O}$ & $\mathrm{Na}_{2} \mathrm{O}$ & $\mathrm{Fe}_{2} \mathrm{O}_{3}$ & $\mathrm{Al}_{2} \mathrm{O}_{3}$ & $\mathrm{SO}_{3}$ & TOTAL \\
\hline 9.05 & 0.45 & 37.7 & 7.6 & 33.1 & 87.9 \\
\hline 9.20 & 0.22 & 44.30 & 2.83 & 32.5 & 89.1 \\
\hline 8.12 & 1.05 & 45.47 & 2.40 & 32.89 & 89.9 \\
\hline \multicolumn{2}{|c|}{ A site } & \multicolumn{2}{|c|}{ B site } & \multicolumn{2}{|c|}{$X$ site } \\
\hline 0.93 & 0.07 & 2.28 & 0.72 & \multicolumn{2}{|c|}{2} \\
\hline 0.96 & 0.03 & 2.73 & 0.27 & \multicolumn{2}{|c|}{2} \\
\hline 0.84 & 0.16 & 2.77 & 0.23 & \multicolumn{2}{|c|}{2} \\
\hline
\end{tabular}

\subsection{Supergene mineralogy - Oxide sector}

The Au distribution and mineralogy of borehole Pd10 is shown in Fig. 2. The location of the borehole along with the large number of drill core samples studied (ranging in depth from $40 \mathrm{~m}$ to 262 $\mathrm{m}$ from the surface) provide a reliable profile on the distribution of hypogene and supergene phases identified in the ore, and insights on the geochemical environment prevailing during oxidation relative to depth.

Goethite and hematite are the predominant secondary phases identified in the oxidation zone (Tabl. 1, Fig. 2). Major textural forms in the oxide sec- tor include patches of fine-grained goethite and hematite associated with finegrained kaolinite between quartz clasts. Scarce pseudomorphs of goethite after euhedral pyrite are also identified at lower levels of the oxide sector with minor anglesite (after galena) and other secondary hydrous Fe-sulfates (Tabl. 1). Jarosite is identified in the lower level of the oxide sector and is usually enriched in $\mathrm{Al}$ with ranging $\mathrm{Na}$ content (Tabl. 3). Jarosite is closely associated with pyrite oxidation, forming anhedral grains around pyrite crystals. In the oxide sector, quartz is the predominant gangue mineral (Tabl. 1) appearing in two major forms. 


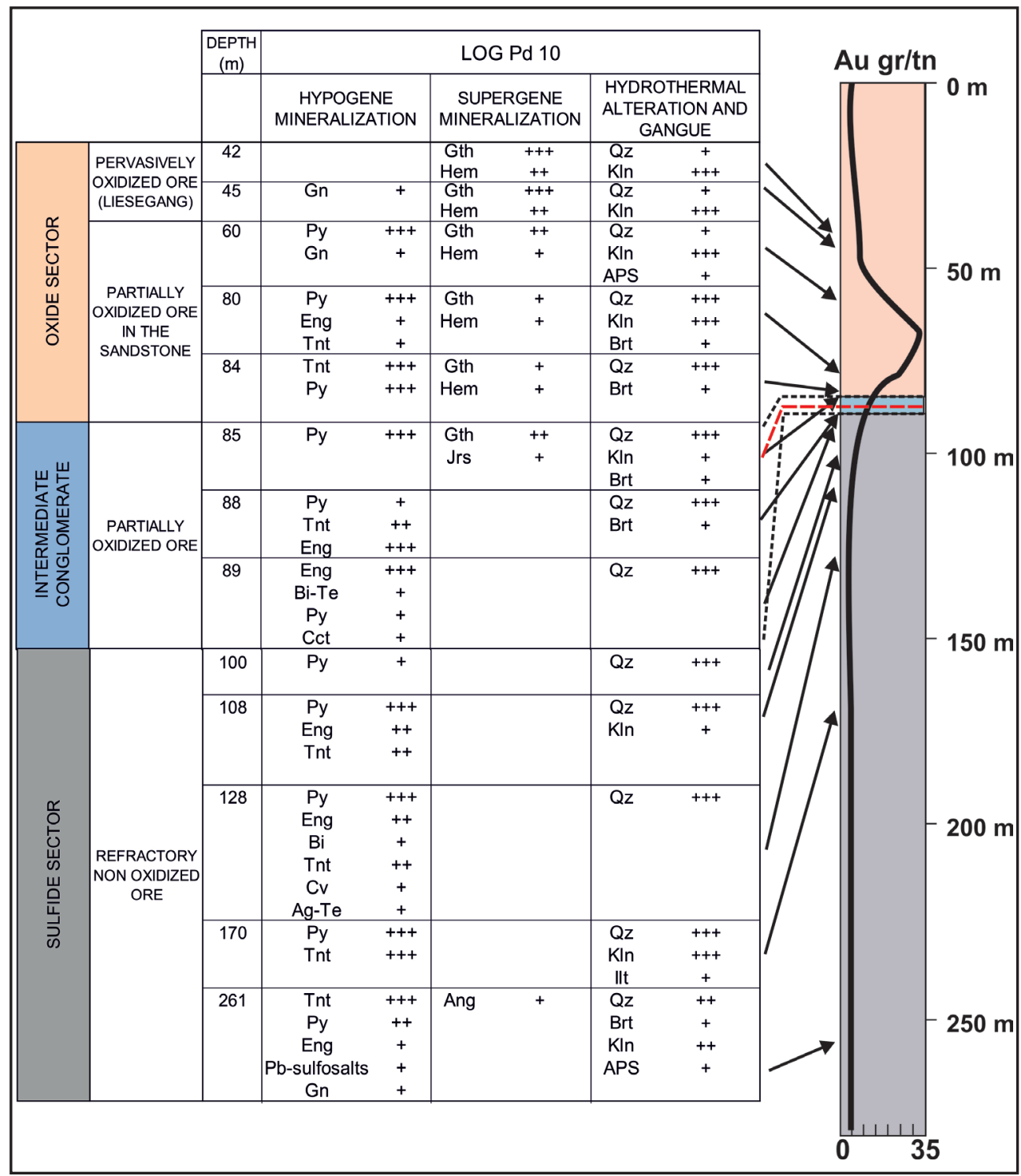

Fig. 2. Lithological, mineralogical and geochemical fingerprint of borehole PD10 (after Skarpelis et al., 2006 with modifications). The Au distribution with depth was provided by courtesy of Thracean Gold Mining S.A. Abbreviations: Gn - galena, Py - pyrite, Eng - enargite, Tnt - tennantite, Bi-Te - Bi-tellurides, Bi - bismuth, Cv - covellite, Ag-Te - Ag-tellurides, Gth - goethite, Hem - hematite, Jrs - jarosite, Ang - anglesite, Qz quartz, KIn - kaolinite, APS - Aluminum phosphates-sulfates, Brt - barite, Ilt - illite (after Whitney and Evans, 2010). (+++) major mineral constituents, (++) minor constituents, (+) subordinate constituents. Thick dashed red line indicates the limit of the oxidation zone.

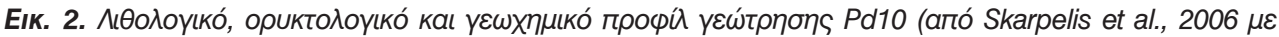

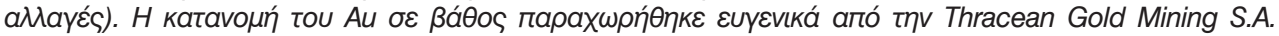

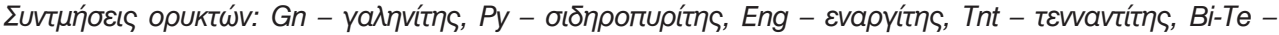

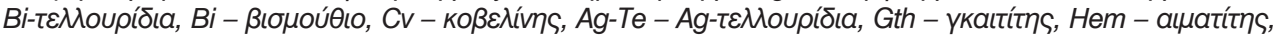

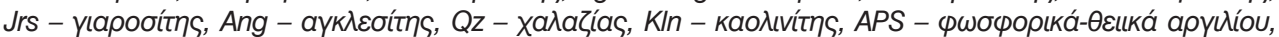

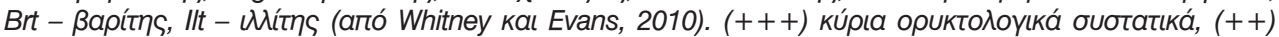

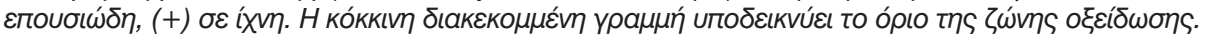


The first involves angular and subangular quartz and polycrystalline quartz clasts, while the second one includes finegrained euhedral to subhedral quartz with its size ranging between 5 and $10 \mu \mathrm{m}$ accompanied by fine-grained kaolinite and/ or barite and is associated with hydrothermal alteration (silicification and argillic alteration). Kaolinite is the second most abundant gangue mineral after quartz. Aggregates of fine-grained crystals predominate, forming patches and filling voids between sandstone clasts and hydrothermal euhedral quartz. Minor pseudomorphs of kaolinite replacing detrital K-feldspar are also identified and limited to the upper part of the sandstone. Kaolinite pseudomorphs are also found at near-surface samples of the devitrified andesites at the northern part of the deposit. Further studies including oxygene isotope analyses on kaolinite samples from the oxide sector of the deposit are required to discriminate between hypogene and supergene origin. Illite is the second most abundant argillic phase after kaolinite. It is found mostly in the upper part of the overlying sandstone replacing micas, and in nearsurface andesites replacing euhedral feldspars. Barite was identified in the majority of the analyzed samples. Barite crystals are euhedral to anhedral with size ranging from a few $\mu \mathrm{m}$ to several $\mathrm{mm}$ in length, and show typical characteristics of late stage deposition. Barite crystals are either found in quartz-barite veins and veinlets or as disseminations of large euhedral crystals between quartz clasts.

\begin{tabular}{|c|c|c|c|c|c|c|c|c|c|c|c|c|c|}
\hline Sample & pH & Eh & CND & $\mathrm{SO}_{4}$ & As & Cd & Co & $\mathrm{Cu}$ & $\mathrm{Fe}$ & Mn & $\mathrm{Ni}$ & $\mathbf{P b}$ & Zn \\
\hline \multicolumn{14}{|c|}{ June 2003} \\
\hline P1 & 3.2 & 227 & 3570 & 1700 & bdl & bdl & 0.283 & 0.012 & 8.8 & 10.4 & 0.16 & bdl & 0.7 \\
\hline \multicolumn{14}{|c|}{ October 2003} \\
\hline $\mathrm{P} 1$ & 3.3 & 221 & 3530 & 2600 & 0.04 & 0.003 & 0.302 & 0.014 & 5.7 & 9.8 & 0.16 & bdl & 0.6 \\
\hline $\mathrm{P} 2$ & 4.1 & 171 & 4420 & 5400 & 0.02 & 0.003 & 0.618 & 0.004 & 39.4 & 10.1 & 0.32 & 0.025 & 6.2 \\
\hline P3 & 4.1 & 170 & 3180 & 2000 & 0.02 & bdl & 0.479 & bdl & 23.1 & 7.8 & 0.26 & bdl & 0.1 \\
\hline \multicolumn{14}{|c|}{ Detection limits } \\
\hline & & & & & 0.002 & 0.002 & 0.002 & 0.002 & 0.01 & 0.002 & 0.005 & 0.005 & 0.002 \\
\hline \multicolumn{14}{|c|}{ Reproducibility (\%) } \\
\hline & \pm 0.03 & & & \pm 5.25 & \pm 0.02 & \pm 0.002 & \pm 0.006 & \pm 0.0007 & \pm 2.21 & \pm 0.01 & \pm 0.07 & \pm 0.007 & \pm 0.04 \\
\hline $\begin{array}{l}\text { bdl: belo } \\
\text { Silver, H } \\
\text { Sample } \\
\text { P1: N40 } \\
\text { P2: N40 } \\
\text { P3: } \text { N40 }^{\circ}\end{array}$ & $\begin{array}{l}\text { detec } \\
\text { and S } \\
\text { ordin } \\
47.1 \\
43.9 \\
10.0\end{array}$ & $\begin{array}{l}\text { on lir } \\
\text { belor } \\
\text { es: } \\
\text { E25 } \\
\text { E25 } \\
\text { E25 }\end{array}$ & $\begin{array}{l}7 \% 44.8^{\prime \prime} \\
8^{\prime \prime} 02.8^{\prime \prime} \\
7^{\prime \prime} 31.0^{\prime \prime}\end{array}$ & 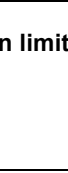 & DI d & $\mathbf{p l}$ & alyz & & & & & & \\
\hline
\end{tabular}

The mineralogy of samples studied by SEM, XRD and optical microscopy studies revealed that the physicochemical environment, related to the lower sulfide sector, changes rapidly at the transition zone between the andesitic breccia and the overlying sandstone. Secondary, supergene phases are present indicating that supergene alteration phenomena have affected the disseminated ore hosted in the felsic sandstone. Mineralogical studies of drill core samples reveal that the lower limit of the oxidation zone roughly follows the boundary between the andesitic brec- cia and the sandstone and reaches approximately $100 \mathrm{~m}$ at depth at the center $(90 \mathrm{~m}$ for borehole Pd10, Fig. 2), whereas is limited at the sides of the deposit ranging from 20 to 25 $m$ from the surface (Fig. 1C) (Skarpelis et al., 2006; Triantafyllidis, 2006).

Pervasive oxidation is identified in near surface samples with a maximum depth of 45 to $50 \mathrm{~m}$ at the center (Fig. 2). Liesegang bands, scarce remnants of pyrite and tennantite, significant load in secondary goethite and hematite as impregnations with fine-grained kaolinite (Fig. 3B) and disseminated native Au 
(Skarpelis et al., 2006) characterize the upper, extensively leached and oxidized part of the deposit. Highly insoluble anglesite replacing galena is the only supergene phase observed in the upper part of the oxide sector. At the lower levels of the Perama sandstone and up to the transition zone with
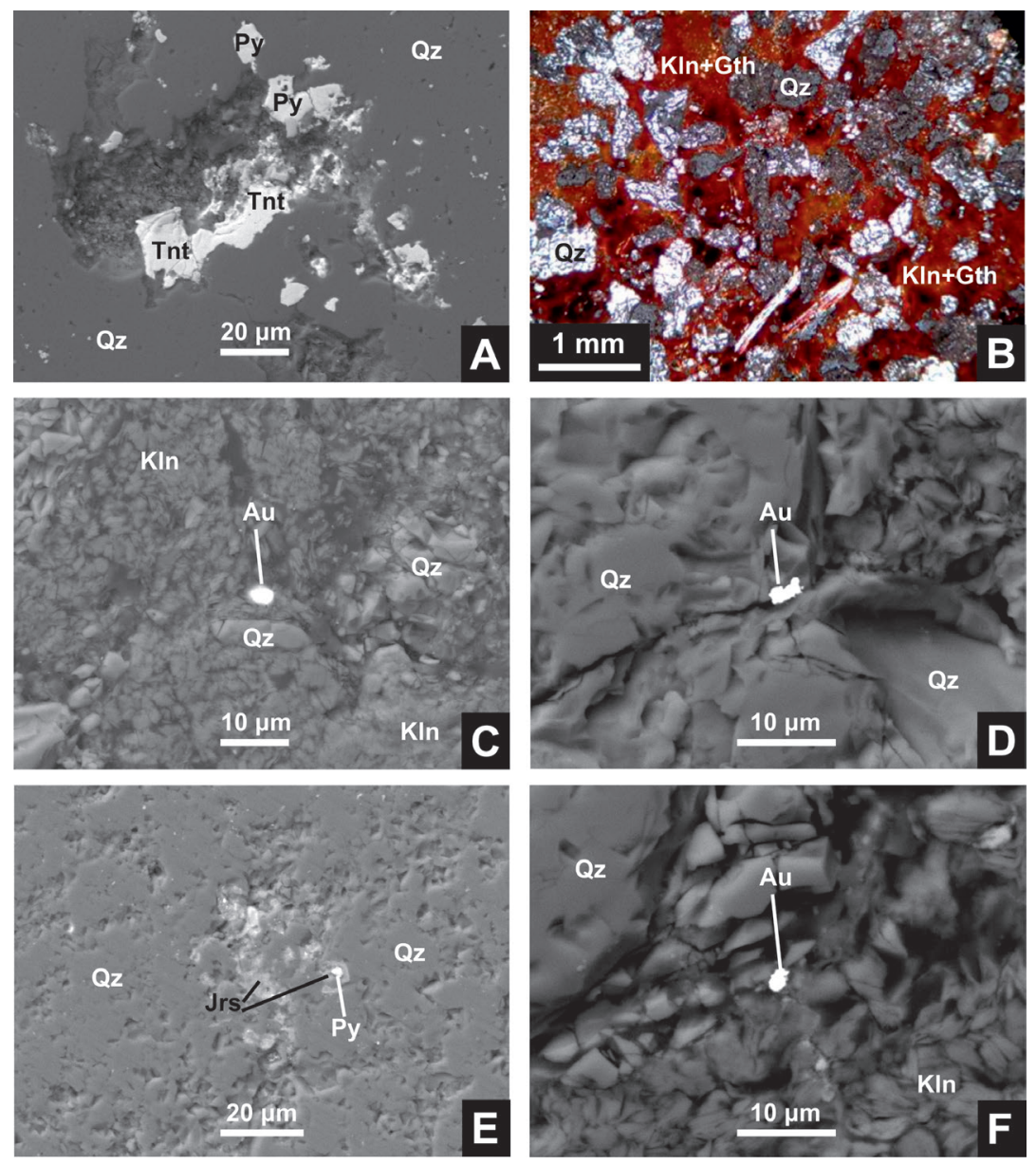

Fig. 3. A. Tennantite in association with pyrite in the sulfide sector. B. Impregnations of goethite and hematite in kaolinite patches between angular-subangular quartz clasts in the upper, penvasively altered part of the oxide sector. C. Free Au grains from the upper part of the oxide sector. D. Free Au grain from the lower part of the oxide sector. E. Pyrite alteration to jarosite at the lower level of the oxide sector. F. Free Au grains from the lower part of the oxide sector near the transition zone.

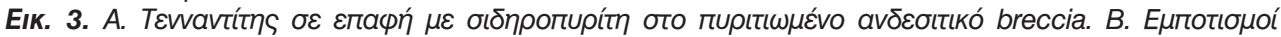

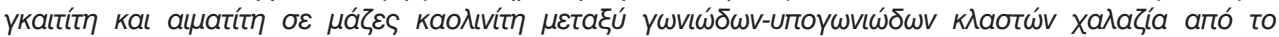

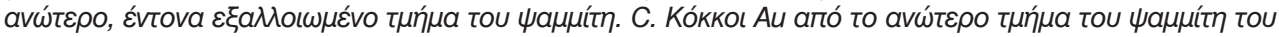

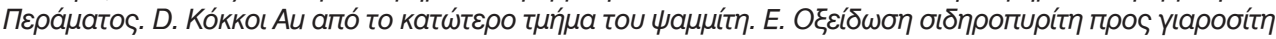

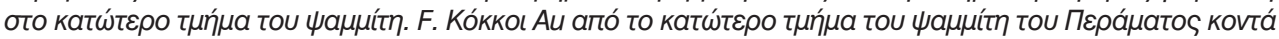

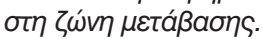


Supergene alteration phenomena are active as it is proved by the quality of surface and ground water samples collected in the vicinity of the Perama Hill deposit. All samples fall into the quality range of waters draining several epithermal deposits globally (Koyanagi and Panteleyev, 1993; Plumlee et al., 1995; Skarpelis and Triantafyllidis, 2004). In particular, the drainage waters are characterized by increased $\mathrm{Fe}, \mathrm{Mn}$ and $\mathrm{Ni}$ content and very low concentrations of $\mathrm{Cu}, \mathrm{Pb}$ and $\mathrm{As}$, whereas the $\mathrm{Fe}$ content decreases along with distance distance to the ore deposit (Tabl. 4). The surface and ground water samples collected in the vicinity of the Perama Hill deposit are characterized as acidic to extreme acidic with high metal load when plotted on a Ficklin diagram with $\mathrm{pH}$ values less than 5.5 and total heavy metal load higher than $1 \mathrm{mg} / \mathrm{L}$ (Triantafyllidis, 2006).

\subsection{Native Gold}

Optical microscopy and SEM studies proved that native Au grains, with ranging $\mathrm{Ag}$ content, are present in the oxide sector of the Perama Hill epithermal deposit. Free Au predominates in the upper (depth up to $10 \mathrm{~m}$ from the surface) and the lowermost part of the Perama sandstone, near the transition zone between the sandstone and the sulfidic ore. That observation is in line with Juras et al. (2010) who state that the highest gold grades are identified in drill core samples from the upper and the lower part of the oxide sector. In the oxide sector, native $\mathrm{Au}$ is either associated with Kaolinite and goethite, or it appears between quazz clasts with size ranging between 1 to $10 \mu \mathrm{m}$ (Figs $3 C, 3 D, 3 F)$. On the other hand, mineralogical investigation of samples from the sulfide sector revealed no free $\mathrm{Au}$ grains.

\section{Discussion}

The distribution of secondary phases in the oxide sector provides insights on the physicochemical conditions and the maturity of the physicochemical environment of both the upper and the lower part of the deposit. Secondary $\mathrm{Fe}$ (III) phases goethite and hematite prevail in the upper part, whereas jarosite and other Fe-sulfates are present at lower levels (Fig. 2). According to Walton-Day (1999), Newbrough and Gammons (2002), Courtin-Nomade et al. (2003), and Fukushi et al. (2003) typical secondary phases in oxidation zones resulting from alteration of Fe-sulfides and sulfosalts include ferrihydrite, schwertmannite, jarosite, goethite and hematite. The stability of those minerals depends on the prevailing physicochemical conditions with increasing $\mathrm{pH}$ and decreasing sulfate load the series of replacement is as follows:

\section{Jarosite $\rightarrow$ schwertmannite $\rightarrow$ ferri- hydrite $\rightarrow$ goethite $\rightarrow$ hematite}

Goethite and hematite are the most stable secondary $\mathrm{Fe}$ (III) phases in mildly acidic to alkaline and oxidative conditions (Nordstrom and Alpers, 1999). It is therefore reasonable to assume that as supergene alteration phenomena progressed, the geochemical environment of the upper part of the oxide sector gradually changed from highly oxidative with increased sulfate load, to mildly acidic and oxidative with very low sulfate content. This pervasive oxidation of the ore is enhanced in the central part of the deposit reaching depths to $45 \mathrm{~m}$ (Fig. 2). The presence of goethite and hematite combined with the absence of secondary sulfates (e.g. jarosite), and the depletion of most heavy metals, based on the geochemical profiles of 
the bore-holes studied, indicate a mature physicochemical environment and progressively increasing $\mathrm{pH}$ and decreasing sulfate load. Liesegang bands also support the hypothesis of mature physicochemical conditions and limited advent flow, since the characteristic rings result from diffusion of oxygen with Fe-rich fluids in poorly lithified sediments (Balsamo et al., 2013; Stegena, 1983). The hypothesis on mature environment is also supported by the enrichment of goethite in As in near-surface samples. In slightly acidic to neutral conditions the concentration of soluble As is controlled by the presence of Fe oxides/hydroxides. Secondary $\mathrm{Fe}(\mathrm{III})$ phases show positive surface charge enabling adsorption of negatively charged anions and oxyanions of As (Smith, 1999; Sracek et al., 2004) with maximum adsorption in $\mathrm{pH}$ between 3 and 5 (Garcia-Sanchez and AlvarezAyuso, 2003).

During the early stages of supergene alteration, the mineralogy of the host sandstone combined with the disseminated mode of occurrence of hypogene minerals and the high potential of pyrite and tennantite to produce highly oxidative agents (Plumlee, 1999), enhanced oxidation phenomena resulting in liberation of microparticulate $\mathrm{Au}$. In oxidative near-surface environments of sulfide deposits two major mechanisms of Au solubility exist, metastable thiosulfate (Webster, 1986; Renders and Seward, 1989) and chloride complexes (Mann, 1984; Webster and Mann, 1984; Stoffregen, 1986), where the Ag content of free Au may provide insights on the prevailing geochemical conditions. In the presence of chlorides, $\mathrm{Ag}$ is more readily dissolved relative to Au (Craw et al., 2015) resulting in Au grains with very low Ag content. Scanning Electron
Microscopy study revealed that free Au grains in the oxide sector of the Perama deposit show a ranging $\mathrm{Ag}$ content (between 1 and 3 wt\%) indicating co-deposition of Au with Ag. It means that thiosulphate-mediated dissolution of $\mathrm{Au}$ was most likely the major Au transport mechanism in early stages of supergene alteration. During the evolution of the upper part of the oxide sector of the Perama Hill deposit, the physicochemical environment changed from acidic and oxidative, to mature (near-neutral and oxidative). In such conditions, $\mathrm{Au}$ is highly insoluble and is mainly transported as elemental, colloidal Au (Krauskopf, 1951), favoring small scale migration, aggregation and re-deposition as free Au grains (Fig. 3C, 3F).

At the lower levels of the oxide sector, the oxidation phenomena are still active but not pervasive. This view is supported by the varying degree of alteration of hypogene sulfides and sulfosalts. In several occasions pseudomorphs of goethite after pyrite and jarosite grains around pyrite crystals are observed (Fig. 3E). The presence of secondary Fe-sulfates indicates relatively immature environment, oxidative conditions and increased sulfate load (Walton-Day, 1999; Courtin-Nomade et al., 2003), an hypothesis supported by the acidic nature and the high metal load of surface and groundwaters draining the Perama sandstone (Tabl. 4). Meteoric waters penetrate the porous sandstone and still attack the disseminated ore comprising pyrite and tennantite resulting in very low quality drainage. It seems that the geochemical environment of the lower part resembles the conditions of the near-surface sector of the deposit during the early stages of supergene alteration. Oxidative, rich in sulfates fluids resulting from on-going oxidation of 
sulfides and sulfosalts favor solubility of $\mathrm{Au}$ as thiosulfate complexes. As physicochemical conditions change near the transition zone between the oxide and the sulfide sector of the deposit, aggregation and reprecipitation of native $\mathrm{Au}$ grains among quartz clasts occurs (Fig. $3 D$ ), resulting in enrichment of the lower part of the oxide sector in gold (Fig. 2). The mode of occurrence of Au in the oxide sector of the Perama Hill deposit is a combination of detrital, later hydrothermal and subsequent supergene alteration mineralogy. The Perama sandstone is characterized by uniform mineral assemblage with abundant quartz, kaolinite, minor illite and traces of K-feldspar. As stated by Lescuyer et al. (2003), the Perama sandstone contains angular to subangular fragments of the basement metamorphic rocks (quartz grains and polycrystalline quartz clasts and mica), as well as glass shards and pyroclastic fragments related to felsic eruptions of the Petrota graben. The immature, felsic sandstone is characterized by increased porosity (coarse, angular to subangular clasts, Fig. 3B). That porosity played a very important role when the sandstone was later affected by hydrothermal activity related to the original high sulfidation mineralogy and the final development of the intermediate sulfidation system. Acidic hydrothermal fluids followed feeders and conduits, and also diffused in the porous media, resulting in extensive hypogene alteration of detrital feldspars and micas to fine-grained kaolinite that filled voids and cracks in the Perama sandstone, providing the final assemblage with very low acid buffering capacity. Uplift and subsequent supergene alteration resulted in oxidation of hypogene disseminated sulfides and sulfosalts, liberation of microparticulate $\mathrm{Au}$, migration, aggregation and deposition of free $\mathrm{Au}$ grains.

\section{Conclusions}

Extensive supergene alteration phenomena have affected the upper part of the Perama Hill epithermal mineralization hosted in the felsic sandstone, whereas oxidation is very limited at the lower sulfide sector. It seems that rock heterogeneity between the underlying andesitic breccia and the overlying porous sandstone played a critical role in development of the texture of the mineralization and the following geologic evolution. The disseminated nature of the ore, with pyrite being the predominant sulfide, combined with the texture and limited acid-buffering capacity of the host sandstone favored penetration of slightly acidic and oxidative meteoric waters and subsequent oxidation phenomena. Goethite and hematite predominate at the uppermost part of the deposit, whereas secondary phases of other heavy metals occur as minor constituents (e.g. anglesite), or are lacking (e.g. $\mathrm{Cu}$ and $\mathrm{Zn}$ ) revealing pervasive supergene oxidation and leaching. At lower levels secondary Fe sulfates are identified, indicating locally highly acidic and oxidative conditions and immature geochemical environment. Free $\mathrm{Au}$ grains are observed in the upper and lowermost part of the oxide sector of the deposit, observation that is in line with statements by Juras et al. (2010). Oxidation phenomena still affect the disseminated ore and enrich the ore in free $\mathrm{Au}$ near the transition zone between the underlying andesitic breccia and the overlying sandstone. Supergene alteration phenomena are active till this day as proved by the acidic and oxidative and rich in heavy metals, surface and ground drainage at the Perama sandstone. 


\section{Acknowledgements}

Part of the research work was funded through the program "IRAKLEITOS Fellowships for Research of National and Kapodistrian University of Athens - ENVIRONMENT". We thank Prof. M. Vavelidis and Ass. Prof. St. Kalaitzidis for their constructive reviews.

\section{References}

Balsamo, F., Bezzera, F.H.R., Vieira, M.M. Storti, F., 2013. Structural control on the formation of iron-oxide concretions and Liesegang bands in faulted, poorly lithified Cenozoic sandstones of the Paraíba Basin, Brazil. Bulletin of GSA, 125, 5-6, 913931.

Border, A.L.M., Michael, C., Constantinides, D., 1999. Discovery and evaluation of the Sappes gold deposits, NE Greece. New Generation GOLD 99, Perth, Western Australia.

Bridges, P. S., Gordon, M. J., Michael, C., Abatzioglou, M., 1997. Gold mineralization at Sappes, Northern Greece. Irish Association for Economic Geology Ltd, 95-107.

Christofides, G., Soldatos, T., Eleftheriadis, G., Koroneos, A., 1998. Chemical and isotopic evidence for source contamination and crustal assimilation in the Hellenic Rhodope plutonic rocks. Acta Vulcanologica, 10, 305-318.

Courtin-Nomade, A., Bril, H., Neel, C., Lenain, J-F., 2003. Arsenic in iron cements developed within tailings of a former metalliferous mine-Enguiales, Aveyron, France. Applied Geochemistry, 18, 9, 395-408.

Craw,D., MacKenzie, D., Grieve, P., 2015. Supergene gold mobility in orogenic gold deposits, Otago Schist, New Zealand. New Zealand Journal of Geology and Geophysics (DOI:
10.1080/00288306.2014.997746).

Dill, H.G., 2001. The geology of aluminium phosphates and sulphates of the alunite group minerals: a review. Earth-Science Reviews, 53, 35-93.

Eleftheriadis, G., 1990. Petrology and geochemistry of the Oligocene volcanic rocks from the Central Rhodope Massif (N. Greece). Geol. Rhodopica, 2, 180-196.

Fukushi, K., Sasaki, M., Sato, T., Yanase, N., Amano, H., Ikeda, H., 2003. A natural attenuation of arsenic in drainage from an abandoned arsenic mine dump. Applied Geochemistry, 18, 9, 1267-1278.

Garcia-Sanchez, A., Alvarez-Ayuso, E., 2003. Arsenic in soils and waters and its relation to geology and mining activities (Salamanca Province, Spain). Journal of Geochemical Exploration, 80, 69-79.

Jambor, J.L., 1999. Nomenclature of the alunite supergroup. Canadian Mineralogist, 37, 1323-1341.

Juras, S., Miller, R., Perkins, P., 2010. Technical Report, of the Perama Hill Project, Thrace, Greece. Unpublished Report, Eldorado Gold Corporation, 144p.

Koyanagi, V.M., Panteleyev, A., 1993. Natural acid drainage in the Mount Macintosh/Pemberton Hills area, northern Vancouver Island (92L/12), in: Grant, B. et al. (Eds), Geological fieldwork 1992 - a summary of field activities and current research: Ministry of Energy, mlnes, and Petroleum Resources, Report 1993-1, 445450.

Krauskopf, K.B., 1951. The solubility of gold. Econ. Geol. 46, 858-870.

Krohe, A., Mposkos, E., 2002. Multiple generations of extensional detachments in the Rhodope Mountains (northern Greece): evidence of epi- 
sodic exhumation of high-pressure rocks, in: Blundell, D.J., Neubauer, F., VonQuadt, A., (Eds.), The Timing and Location of Major Ore Deposits in an Evolving Orogen. Geological Society, London, Special Publication, 204, 151-178.

Lescuyer, J.L., Baily, L., Cassard, D., Lips, A.L.W., Piantone, P., McAlister, M., 2003. Sediment-hosted gold in south-eastern Europe: the epithermal deposit of Perama, Thrace, Greece. 7th Biennial SGA Meeting, Mineral Exploration and Sustainable Development, Athens, 499-502.

Mann, A.W., 1984. Mobility of gold and silver in lateritic weathering profiles; some observations from Australia. Econ. Geol., 79, 38-49.

Marschik, R., Schmidt, E., Falalakis, G., Hölzl, S., 2011. The Perama Hill gold deposit, NE Greece: Strontium, lead, and sulfur isotope signature of the hypogene mineralization, in: Barra F. et al. (Eds) Let's Talk Ore Deposits, 11th Biennial SGA Meeting of The Society for Geology Applied to Mineral Deposits, Antofagasta, Chile, 496-498.

McAlister, M., Hammond, M.J., Normand, D., Kampasalakis, M., 1999. Discovery case history for the Perama Hill Gold deposit, Greece, in: Currie, D., Nielsen, K., (Eds). New Generation Gold Mines 99, Case Histories of Discovery, Perth, Australia, 39-49.

Michael, C., Constantinides, D., Ashworth, K., Perdikatsis, V., Demetriades, A., 1989. The Kirki vein polymetallic mineralization, NE Greece. Geologica Rhodopica, 1, 366-373.

Michael, C., Papadopoulos, P., Marantos, I., Evangelou, E., 1988. Epithermal gold mineralization in Konos area, Institite of Geology and Mineral
Exploration, Athens, [in Greek]. 23p. Michael, C., Perdikatsis, V., Dimou, E., Marantos, I., 1995. Hydrothermal alteration and ore deposition in epithermal precious metal deposit of Agios Demetrios, Konos area, northern Greece. Geol. Soc. Greece, Special Publication, 4, 2, 778-782.

Newbrough, P., Gammons, C.H., 2002. An experimental study of water-rock interaction on acid rock drainage in the Butte mining district, Montana. Environmental Geology, 41, 705-719. Nordstrom, D.K., Alpers, C.N., 1999. Geochemistry of acid mine waters, in: Plumlee, G.S., Logsdon, M.J., (Eds.), Reviews in Economic Geology, 6A. The Environmental Geochemistry of Mineral Deposits. Part A: Processes, Techniques, and Health Issues, Society of Economic Geologists, 133-160.

Pecskay, Z., Eleftheriadis, G., Koroneos, A., Soldatos, T., Christofides, G., 2003. K/Ar dating, geochemistry and evolution of the tertiary volcanic rocks (Thrace, Northeastern Greece). 7th Biennial SGA Meeting, Mineral Exploration and Sustainable Development, Athens, 1229-1232.

Plumlee, G.S., 1999. The environmental geology of mineral deposits, in: Plumlee, G.S., Logsdon, M.J., (Eds.), Reviews in Economic Geology, 6A. The Environmental Geochemistry of Mineral Deposits, Part A: Processes, Techniques, and Health Issues, Society of Economic Geologists, 71116.

Plumlee, G.S., Smith, K.S., Mosier, E.L., Ficklin, W.H., Montour, M., Briggs, P.H., Meier, A.L., 1995. Geochemical processes controlling acid-drainage generation and cyanide degradation at Summitville, in: Posey, H.H., Pendleton, J.A., VanZyl, D., (Eds.), Sum- 
mitville Forum, Colorado Geological Survey Spec. Pub. 38, 23-34.

Renders, P.J.N., Seward, T.M., 1989. The stability of hydrosulphido- and sulphido-complexes of $\mathrm{Ag}(\mathrm{I})$ and $\mathrm{Au}$ (I) at $25^{\circ} \mathrm{C}$. Geochim. Cosmochim. Acta, 53, 245-253.

Scott, K.M., 1987. Solid solution in and classification of gossan-derived members of the alunite jarosite family, Northwest Queensland, Australia. American Mineralogist, 72, 178-187.

Shaw, A.J., Constantinides, D.C., 2001.

The Sappes gold project. In: Marinos et al. (Eds.), 9th Inter. Congr. Geol. Soc. Greece, Athens, 10731080.

Smith, K.S., 1999. Metal sorption on mineral surfaces: an overview with examples relating to mineral deposits, in: Plumlee, G.S., Logsdon, M.J., (Eds.), Reviews in Economic Geology, 6A. The Environmental Geochemistry of Mineral Deposits. Part A: Processes, Techniques, and Health Issues, Society of Economic Geologists, 161-182.

Skarpelis, N., Triantafyllidis, S., 2004. Environmental impact form supergene alteration and exploitation of a high sulphidation epithermal type mineralisation (Kirki, NE Greece). Applied Earth Science, Trans. Inst. Min. Metall. B, 113, 1, 110-116.

Skarpelis, N., Economou, M., Michael, K., 1987. Geology, petrology and polymetallic ore types in a Tertiary volcanosedimentary terrain, ViriniPessani-Dadia area, West Thrace (Northern Greece). Geologica Balcanica, 17, 6, 31-41.

Skarpelis, N., Triantafyllidis, S., Falalakis, G., 2006. The Perama intermediate sulfidation epithermal Au system (Thrace, Greece): Hypogene mineralogy and supergene alteration.
Neogene Magmatism of the Central Aegean and Adjacent Areas: Petrology, Tectonics, Geodynamics, Mineral Resources and Environment, Milos, Cyclades, Greece, abstracts vol., p37.

Skarpelis, N., Voudouris, P., Arikas, K., 1999. Exploration for epithermal Gold in SW Thrace (Greece): New target areas, in Stanley, C.J. et al. (Eds.) Mineral Deposits: Processes to Processing, Rotterdam: Balkema, 589-592.

Sracek, O., Bhattacharya, P., Jacks, G., Gustafsson, J-P., VonBromssen, M., 2004. Behavior of arsenic and geochemical modeling of arsenic enrichment in aqueous environments. Applied Geochemistry, 19, 169-180.

Stegena, L., 1983. Leaching in rocks: some physical principles, in: Augustithis, S.S., (Eds.), Leaching and diffusion in rocks and their weathering products, Theophrastus Publications, Athens, Greece, 81-92pp.

Stoffregen, R., 1986. Observations on the behavior of gold during supergene oxidation at Summitville, Colorado, USA, and implications for electrum stability in the weathering environment. Applied Geochemistry, 1, 549-558.

Struntz, H., Tennyson, C., 1982. Mineralogische Tabellen. Akademische Verlagsgesellschaft Geest and Portig, Leipzig, 621p.

Triantafyllidis, S., 2006. Environmental risk assessment of mining and processing activities and rehabilitation proposals in Evros and Rhodope prefectures (Thrace, NE Greece). Unpublished PhD Thesis (in Greek with English abstract), Faculty of Geology \& Geoenvironment, University of Athens, 361p.

Voudouris, P., Melfos, V., Vavelidis, 
M., Arikas, K., 2003. Genetic relation between the Tertiary porphyry $\mathrm{Cu}-( \pm \mathrm{Mo})$ and the epithermal Au$( \pm \mathrm{Ag})$ deposits in the Rhodope metallogenic province, Thrace region, Northern Greece. 7th Biennial SGA Meeting, Mineral Exploration and Sustainable Development, Athens, 541-544.

Voudouris, P., Papavassiliou, C., Alfieris, D., Falalakis, G., 2007. Gold-silver tellurides and bismuth sulfosalts in the high-intermediate sulfidation Perama Hill deposit, western Thrace (NE Greece). Geological Survey of Finland, Guide 53, 77-84.

Walton-Day, K., 1999. Geochemistry and processes that attenuate acid mine drainage in wetlands, in: Plumlee, G.S., Logsdon, M.J., (Eds.), Reviews in Economic Geology, 6A. The
Environmental Geochemistry of Mineral Deposits. Part A: Processes, Techniques, and Health Issues, Society of Economic Geologists, 215228.

Webster, J.G., 1986. The solubility of gold and silver in the system $\mathrm{Au}-\mathrm{Ag}$ $-\mathrm{S}-\mathrm{O} 2-\mathrm{H} 2 \mathrm{O}$ at $25^{\circ} \mathrm{C}$ and $1 \mathrm{~atm}$. Geochim. Cosmochim. Acta, 50, 18371845.

Webster, J.G., Mann, A.W., 1984. The influence of climate, geomorphology and primary geology on the supergene migration of $\mathrm{Au}$ and $\mathrm{Ag}$. Journal of Geochemical Exploration, 22, 21-42.

Whitney, D.L., Evans, B. W., 2010. Abbreviations for names of rock-forming minerals. American Mineralogist, 95, 185-187. 